\title{
Analisis QoS Open IMS Core berbasis Network Function Virtualization pada Protokol TCP
}

\author{
Nizam Khoirunnidzom ${ }^{1 *}$, Dadiek Pranindito ${ }^{2}$, Syariful Ikhwan ${ }^{3}$ \\ 1,2,3Program Studi Teknik Telekomunikasi,IT Telkom Purwokerto \\ 1,2,3 Jln. D.I. Panjaitan No.128 Purwokerto, 53163, Indonesia \\ email: ${ }^{1}$ 14101104@ittelkom-pwt.ac.id, ${ }^{2}$ dadiek@ittelkom-pwt.ac.id, ${ }^{3}$ syariful@ittelkom-pwt.ac.id
}

Copyright $\odot 2019$, Politeknik Harapan Bersama, Tegal

\begin{abstract}
IP Multimedia Subsystem (IMS) is an NGN technology to convergence support of wireline and wireless networks with QoS guarantees. Therefore IMS is widely used by telecommunications operators. Increasing customers make operators overwhelmed by having to replace or add new devices to increase IMS capacity, which is less profitable for operators on the operational costs. The concept of Network Function Virtualization (NFV) is solve the problem. The concept changed of hardware-dedicated to software-dedicated in a virtual environment allows the NFV to be more flexible in increasing device capacity and can reduce dependence on hardware purchases. In this research IMS implemented using Open IMS Core and NFV infrastructure software using OpenStack. analysis based on QoS file transfer services and web servers by measuring parameters throughput, delay, jitter, and packet loss. Based on the measurement of QoS parameters obtained by traffic load of 0 Mbps, 10 Mbps, 20 Mbps, 30Mbps. The throughput average values on file transfer service are $\mathbf{0 . 2 9 0 6}$ Mbit / s and 16.4366 Mbit / s on web server services. The delay average value on file transfer service is $25.5077 \mathrm{~ms}$ and 0.7708 ms on the web server service. The resulting jitter value is $<1 \mathrm{~ms}$. Percentage of packet loss is $<1 \%$.
\end{abstract}

Abstrak - IP Multimedia subsystem (IMS) merupakan teknologi NGN untuk mendukung konvergensi jaringan wireline dan wireless dengan jaminan QoS yang baik. Oleh karena itu IMS banyak digunakan oleh operator telekomunikasi. Semakin meningkatnya pelanggan membuat operator kewalahan karena harus mengganti atau menambah perangkat baru untuk meninggatkan kapasitas IMS, di mana hal ini kurang menguntungkan bagi operator pada sisi biaya operasional. Konsep Network Function Virtualization (NFV) menjadi jawaban untuk permasalahan ini. Dengan mengubah konsep hardware-dedicated menjadi software-dedicated pada lingkungan virtual memungkinkan NFV lebih fleksibel dalam peningkatan kapasitas perangkat dan dapat mengurangi ketergantungan pembelian hardware. Dalam penelitian ini diimplementasikan IMS menggunakan Open IMS Core dan software pembangun infrastruktur NFV menggunakan OpenStack. analisis berdasarkan QoS layanan file transfer dan web server dengan mengukur parameter throughput, delay, jitter, dan packet loss. Berdasarkan pengukuran parameter QoS didapatkan dengan beban trafik sebesar 0 Mbps, 10 Mbps, 20 Mbps, 30Mbps. Nilai throughput yang dihasilkan pada layanan file transfer rata-rata adalah $0.2906 \mathrm{Mbit} / \mathrm{s}$ dan $16.4366 \mathrm{Mbit} / \mathrm{s}$

*) Corresponding author: (Nizam Khoirunnidzom)

Email: 14101104@ittelkom-pwt.ac.id pada layanan web server. Nilai delay yang dihasilkan pada layanan file transfer rata-rata adalah $25.5077 \mathrm{~ms}$ dan $0.7708 \mathrm{~ms}$ pada layanan web server. Nilai jitter yang dihasilkan $<1$ ms. Prosentase packet loss $<1 \%$.

Kata Kunci - IMS, Network Function Virtualization, QoS

\section{PENDAHULUAN}

Teknologi Next Generation Network (NGN) menjadi evolusi dalam bidang telekomunikasi yang berbasis Internet Protocol (IP). Teknologi NGN ini dirancang untuk mendukung konvergensi jaringan wireline dan wireless dengan arsitektur jaringannya yaitu IP Multimedia Subsystem (IMS). Kualitas layanan yang baik menjadikan IMS pilihan operator-operator telekomunikasi. Namun, dalam penggunaannya IMS masih berbasis hardware-dedicated dan hal ini menyebabkan pengguanaan IMS menjadi tidak efisien dikarenakan perlunya penggantian server IMS atau penambahan server akibat pengguna layanan yang semakin meningkat. Sehingga hal tersebut menyebabkan Capital Expenditure (CAPEX) atau pengeluaran operasional perusahaan membengkak setiap terjadi penambahan atau pergantian server IMS [1].

Pada perkembangannya, The European Telecommunication Intitute (ETSI) mengeluarkan konsep Network Function Virtualization (NFV). NFV menjadi pilihan untuk menangani permasalah tersebut. Konsep yang ditawarkan NFV yaitu merubah perangkat jaringan yang berbasis hardware-dedicated menjadi software-dedicated dengan metode virtualisasi menggunakan NFV Infrastructure (NFVI) [2]. NFVI merupakan infrastruktur dengan konsep cloud computing. Dengan konsep seperti ini menjadikan penggunaan IMS menjadi lebih efisien tanpa perlu menambah perangkat baru saat pengguna layanan bertambah, cukup dengan upgrade atau melakukan penambahan instances. Karena dalam pengembangan menggunakan cloud computing tidak akan mengganggu sistem lain yang sedang berjalan.

\section{PENELITIAN YANG TERKAIT}

Penelitian mengenai performansi jaringan NFV ini telah dilakukan sebelumnya. Penelitian tersebut menganalisis dari segi cost dan performansi. Hasil yang didapatkan pada implementasi jaringan sesunguhnya terdapat kenaikan cost di setiap penambahan server. Sedangkan pada implementasi 
NFV cost yang dihasilkan konstan di setiap penambahan instance [3].

Penelitian mengenai virtualisasi IMS ini telah dilakukan sebelumnya, yaitu penelitian mengenai implementasi Layanan Instans Messaging berbasis IMS menggunakan Virtual Server. Software pembangun IMS pada jaringan virtual menggunakan Proxmox VE. Percobaan layanan voice call dan video call. Pada percobaan tersebut menghasilkan parameter delay untuk voice dan video call masih memenuhi standar ITU-T yaitu tidak melebihi $150 \mathrm{~ms}$, dan parameter jitter tidak melebihi $30 \mathrm{~ms}$, sehingga layak untuk diimplementasikan [4]. Selain itu berberaoa oenelitian sebelumnya dilakukan oleh [5]-[7]

Berdasarkan permasalahan dan jurnal acuan di atas, fokus dari penelitian ini adalah menganalisis Open IMS Core berbasis Network Function Virtualization pada Protokol TCP

\section{A. Simulasi Penelitian}

\section{METODE PENELITIAN}

Dalam proses pengujian simulasi jaringan dilakukan dengan menggunakan 4 unit hardware yang berupa tiga unit PC yang digunakan untuk membangun infrastuktur NFV, dua unit PC digunakan sebagai pengirim dan penerima, serta satu buah switch untuk menghubungkan setiap hardware. Implementasi topologi jaringan yang digunakan pada saat pengujian simulasi jaringan dapat di lihat pada Gbr 1 .

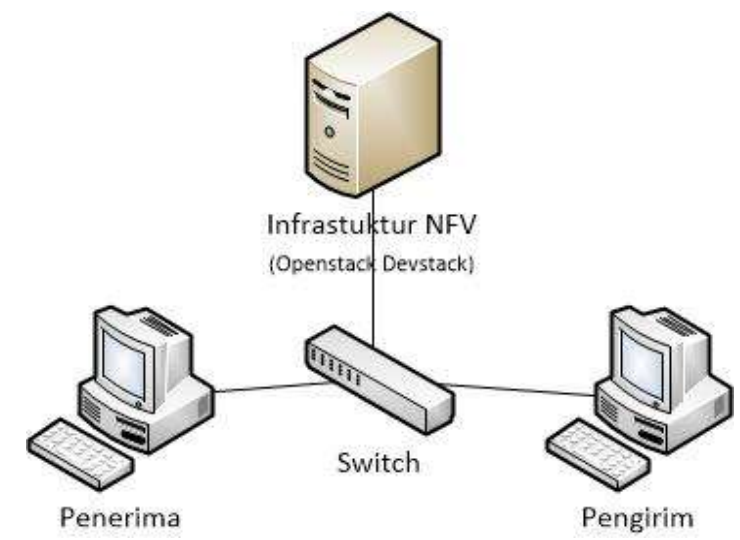

Gbr. 1 Implementasi topologi jaringan

Pada Gbr 1 menampilkan implementasi topologi jaringan dalam pengujian jaringan pada penelitian ini, beradasarkan gambar 1 infrastruktur NFV dibangun menggunakan OpenStack devstack dan dua PC sebagai end device pengirim dan penerima. Pada pengoperasiannya di jaringan internal OpenStack diinstal instace Open IMS Core. Open IMS Core akan bertindak sebagai call control yang bekerja di layer 5, dan pada end device bertindak sebagai interface user untuk komuikasi file transfer melalui aplikasi Boghe IMS Client dan XAMPP sebagai media web server. Selain itu penggunaan aplikasi wireshark di sisi client berfungsi untuk meng-capture informasi paket yang keluar / masuk di sisi client, informasi informasi tersebut yang nantinya akan digunakan sebagai bahan analisa penelitian.

\section{B. Konfigurasi Open IMS CORE}

Perancangan Open IMS Core dilakukan pada instance
Ubuntu dekstop 14.04.5-64bit. Pada Open IMS Core tedapat empat komponen penyusun Open IMS Core diantaranya adalah P-CSCF, I-CSCF, S-CSCF dan FHoSS, instalasi Open IMS Core memerlukan beberapa paket yang akan dicompile pada directory OpenIMSCore.

Untuk mengaktifkan server Open IMS Core dengan menjalankan komponen CSCF diantaranya yaitu, PCSCF yang berperan sebagai pengatur keamanan (proxy) pada server, ICSCF yang berperan untuk mengatur sesi komunikasi, SCSCF yang berfungsi untunk menyajikan aplikasi yang di inginkan pelanggan, serta HSS yang berfungsi sebagai database informasi pelanggan IMS. Pada Gbr.2 menampilkan empat terminal CSCF eksekusi komponen Open IMS Core.

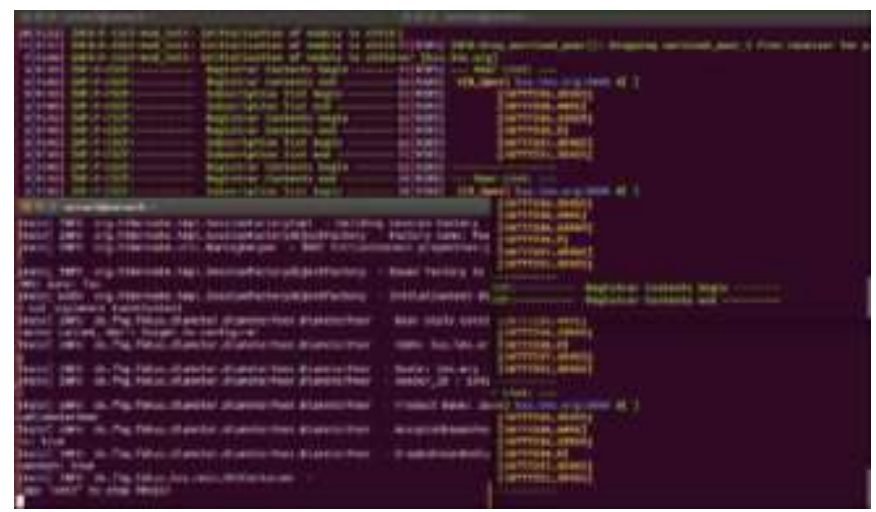

Gbr. 2 Terminal fungsi CSCF Open IMS Core

\section{Konfigurasi Openstack}

Pada penelitian ini menggunakan openstack devstack sebagai infrastuktur pembangun NFV. Openstack devstack merupakan openstack berbasis all-in-one single machine atau beberapa node pembangun openstack dibangun pada satu hardware. Openstack devstack berjalan di atas sistem operasi Ubuntu 16.04 LTS 64 bit.

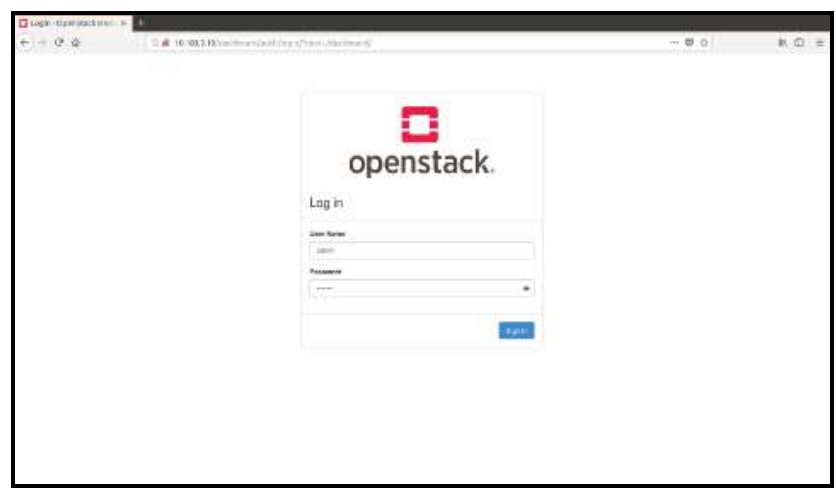

Gbr. 3 Dashboad login OpenStack

Konfigurasi untuk launch instance dengan langkahlangkah yaitu pertama membuat volume pada nova, kemudian membuat private-net dan router yang akan menghubungkan private-net dengan public-net. langkah terakhir adalah launch instance menggunakan image ubuntu 14.04 dengan flavor yang digunakan $\mathrm{m} 1$.small. setelah berhasil launch instance maka akan dapat dilihat pada network topology seperti Gbr 4. 


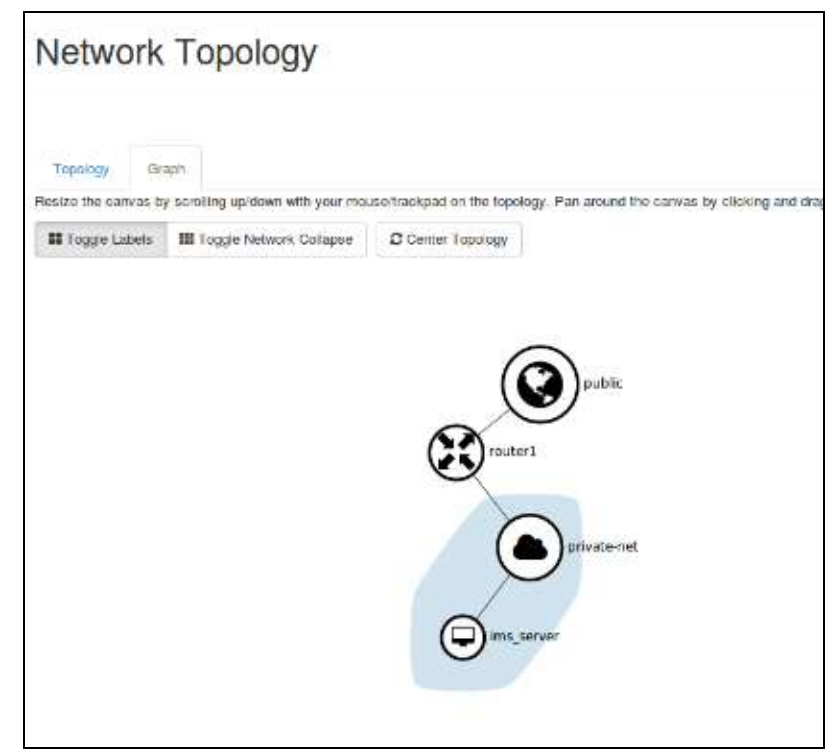

Gbr. 4 Topologi jaringan pada OpenStack

\section{Konfigurasi Boghe IMS Client}

Pada penelitian ini software Boghe IMS/RCS Client digunakan sebagai software instans messaging file transfer dan untuk autentifikasi masing-masing end device. Tampilan komunikasi file transfer ditunjukkan Gbr 5.

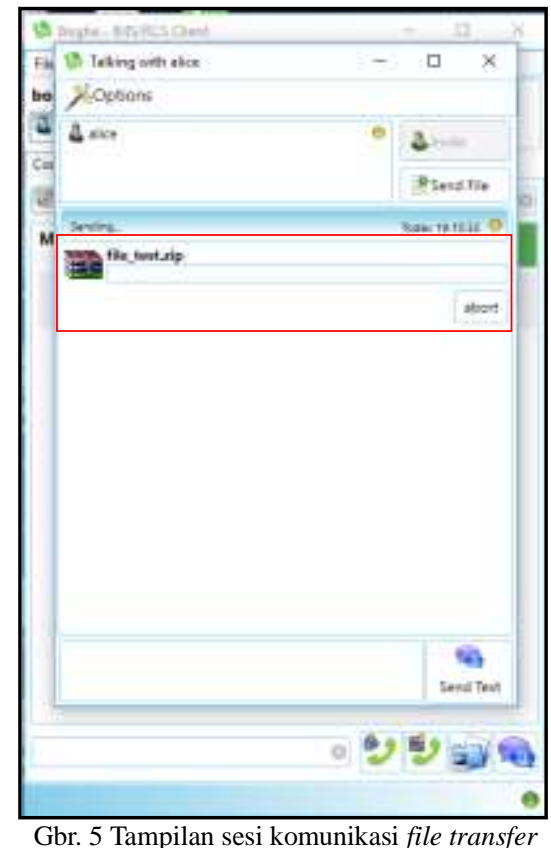

\section{E. Konfigurasi XAMPP}

Konfigurasi untuk pembuatan layanan web server sebagai media file transfer pada layanan web menggunakan software XAMPP. Program apache yang terdapat pada XAMPP digunakan untuk menjalankan, melayani, memfungsikan situs web. Pada saat client akan mengakses situs web server, lakukan authentification pada software Boghe IMS/RCS
Client di sisi pengirim dan penerima. Hal ini dilakukan agar saat mengakses situs terkoneksi dengan jaringan IMS. Setelah login pada Boghe IMS/RCS Client kemudian client penerima akan mengunduh file yang tersedia melalui web browser dengan mengakses alamat IP dari pengirim yaitu 10.180.3.226 seperti yang ditunjukan Gbr 6 .

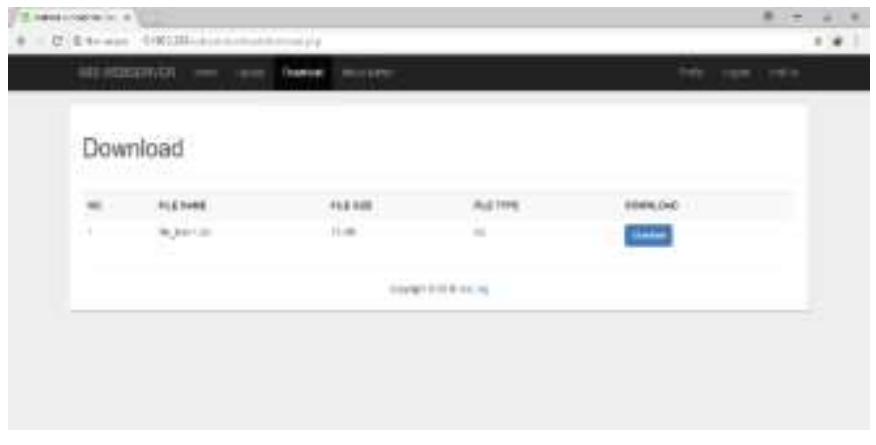

Gbr. 6 Tampilan download pada web server

\section{F. Skenario Pengujian}

Pengujian sistem untuk menguji kinera QoS dari jaringan IMS menggunakan NFV dengan mengimplementasikan layanan file transfer dan web server dengan skenario beban trafik yang dibanjiri pada jaringan. Beban trafik yang digunakan yaitu 0 Mbps, 10 Mbps, 20 Mbps, dan 30 Mbps. Sedangkan parameter yang dianalisis adalah throughput, delay, jitter, dan packet loss.

\section{G. Parameter Analisis Dato}

Pada penelitian analisis kinerja IMS menggunakan NFV, pada layanan file transfer dan web server terdapat empat parameter QoS yang diamati, yaitu:

1) Throughput

Troughput merupakan jumlah total kedatangan bit yang berhasil diamati pada destination selama interval waktu tertentu dibagi oleh durasi waktu pengiriman bit [3].

\section{Troughput $=\frac{\text { (Jumlah bit data yang diterima benar) }}{\text { Waktu pengiriman bit }}$ Bps}

Troughput dalam sistam adalah jumlah bit benar yang diterima dibandingkan dengan waktu pengiriman bit.

\section{2) Delay}

Delay merupakan durasi waktu transmit yang dibutuhkan paket untuk sampai ke tujuan, panjang pendeknya waktu yang dibutuhkan di pengaruhi beberapa faktor yaitu, adanya antrian pengiriman paket yang panjang, proses pengambilan rute lain untuk menghindari kemacetan traffik jaringan dan juga dapat dipengaruhi oleh jarak dan media fisik [8], [9].

$$
\operatorname{Delay}(\mathrm{n})=\mathrm{T}_{\text {out }}(\mathrm{n})=\text { serving time }+\mathrm{T}_{\mathrm{in}}(\mathrm{n})
$$

\section{Dimana:}

$\mathrm{T}_{\text {out }}(\mathrm{n})=$ waktu data ke-n keluar antrian dan siap ditransmisi $\mathrm{T}_{\text {in }}(\mathrm{n})=$ waktu data ke-n masuk antrian [4]. 
TABEL I

STANDAR DELAY TIPHON TR 101329

\begin{tabular}{|c|c|c|}
\hline No & Kategori & Besar Delay $(\mathbf{m s})$ \\
\hline 1 & Baik & $<100$ \\
\hline 2 & Sedang & $<150$ \\
\hline 3 & Kurang & $<400$ \\
\hline
\end{tabular}

\section{3) Jitter}

Jitter merupakan variasi delay pengiriman paket yang terjadi pada jaringan IP antara source dan destination. Besarnya nilai jitter yang dihasilkan dipengaruhi oleh variasi beban trafik dan besarnya tumbukan (congestion) antar paket pada jaringan IP.

TABEL II

STANDAR JITTER BERDASARKAN TIPHON TR 101329

\begin{tabular}{|c|c|}
\hline Kategori & Delay Variation \\
\hline Bagus & $<10 \mathrm{~ms}$ \\
\hline Sedang & $10-20 \mathrm{~ms}$ \\
\hline Buruk & $20-40 \mathrm{~ms}$ \\
\hline
\end{tabular}

\section{4) Packet Loss}

Packet Loss merupakan banyknya paket yang hilang selama proses transmisi data berjalan. Packet Loss disebabkan oleh beberapa faktor yaitu collision dan congestion pada jaringan.

Packet Loss $=\frac{(\text { Packets transmitted -Packets received })}{\text { Packet transmitted }} \times 100 \%$

TABEL III

STANDAR PACKET LOSS TIPHON TR 101329

\begin{tabular}{|c|c|}
\hline Kategori & Packet Loss Ratio (PLR) \\
\hline Bagus & $<0.5 \%$ \\
\hline Sedang & $<1 \%$ \\
\hline Buruk & $<2 \%$ \\
\hline
\end{tabular}

\section{HASIL DAN PEMBAHASAN}

\section{A. Hasil Throughput}

Throughput adalah jumlah bit atau paket dari suatu unit data yang diterima dengan benar oleh penerima. Jumlah ratarata paket data yang sukses dikirimkan oleh semua terminal pada jaringan merupakan definisi dari jumlah throughput. Hasil pengambilan data parameter throughput yang diperoleh berdasarkan pengujian layanan file transfer dan web server dalam beberapa variasi beban trafik ditampilkan pada Tabel IV.

TABEL IV

TROUGHPUT LAYANAN FILE TRANSFER DAN WEB SERVER

\begin{tabular}{|c|c|c|c|c|c|}
\hline \multirow{2}{*}{ Layanan } & \multirow{2}{*}{ Parameter } & \multicolumn{4}{|c|}{ Background Traffic } \\
\cline { 3 - 6 } & & O Mbps & 10 Mbps & 20 Mbps & 30 Mbps \\
\hline $\begin{array}{c}\text { File } \\
\text { Transfer }\end{array}$ & Throughput & 0.2915 & 0.2908 & 0.2904 & 0.2895 \\
\cline { 4 - 6 } $\begin{array}{c}\text { Web } \\
\text { Server }\end{array}$ & Mbps) & 21.1238 & 15.4331 & 14.6624 & 14.5270 \\
\hline
\end{tabular}

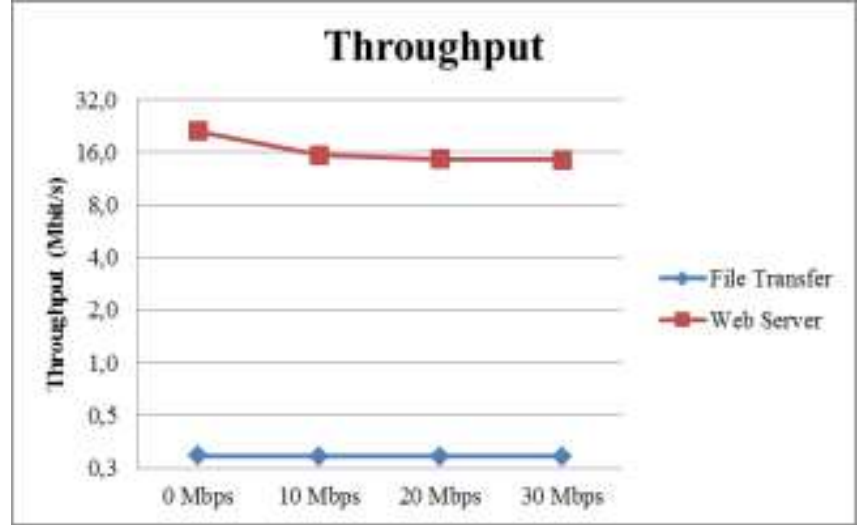

Gbr. 7 Grafik Troughput layanan file transfer dan web server

Dari hasil parameter throughput yang didapatkan berdasarkan gambar 7 , pengambilan dengan beban trafik 0 Mbps pada layanan web server adalah sebesar 21.1238 Mbps sedang kan layanan file transfer adalah sebesar 0.2915 Mbps. Pada skenario pengambilan data dengan beban trafik $10 \mathrm{Mbps}$ didapatkan hasil 15.4331 Mbps pada layanan web server dan 0.2908 pada layanan file transfer. Skenario pengambilan data dengan beban trafik 20 Mbps memperoleh hasil 14.6224 Mbps pada layanan web server dan 0.2904 Mbps pada layanan file transfer. Pada skenario pengambilan data dengan beban trafik $30 \mathrm{Mbps}$ diperoleh nilai throughput 14.5270 Mbps pada layanan web server dan 0.2895 Mbps pada layanan file transfer.

Berdasarkan Gbr 7 hasil yang diperoleh berdasarkan parameter throughput padąlayyanan file transfer lebih kecil dibandingkan pada layanan web server. Hal tersebut terjadi dikarenakan pada layanan file transfer, paket dikirim melalui jaringan IMS menuju user tujuan. Perlu beberapa autentifikasi hingga komunikasi berhasil dilakukan yang ditunjukkan dengan status "COMPLETED". Maka dari itu nilai throughput yang diperoleh lebih kecil.

Sedangkan pada layanan web server pada sisi penerima telah merespon untuk terjadi komunikasi, namun sisi pengirim tidak mengirimkan file tersebut melalui jaringan IMS tetapi langsung diteruskan secara peer to peer. Hal tesebut dapat dilihat pada SIP flows di mana status masih "IN CALL", namun file telah sampai di user tujuan.

\section{B. Hasil Alisis Delay}

Delay merupakan durasi waktu yang dibutuhkan sebuah paket untuk melakukan perjalanan dari pengirim ke penerima. Media transmisi, ukuran paket data dapat mempengaruhi besarnya delay. Hasil pengambilan data parameter delay yang diperoleh pada jaringan Open IMS Core menggunakan NFV dalam skenario yang berbeda, yaitu dengan beban trafik 0 Mbps, 10 Mbps, 20 Mbps dan 30 Mbps. Hasil yang didapatkan adalah semakin besar penambahan beban trafik maka akan semakin besar pula nilai delay yang dihasilkan ditampilkan pada Tabel V.

TABEL V

\begin{tabular}{|c|c|c|c|c|c|}
\hline \multicolumn{1}{c|}{ DELAY LAY ANAN FILE TRANSFER DAN WEB SERVER } \\
\cline { 4 - 6 } Layanan & Parameter & $\mathbf{0}$ Mbps & $\mathbf{1 0}$ Mbps & $\mathbf{2 0}$ Mbps & $\mathbf{3 0 ~ M b p s}$ \\
\hline $\begin{array}{c}\text { File } \\
\text { Transfer }\end{array}$ & Delay (ms) & 25.4637 & 25.5276 & 25.5043 & 25.5350 \\
\cline { 4 - 6 } $\begin{array}{c}\text { Web } \\
\text { Server }\end{array}$ & & 0.581 & 0.824 & 0.8272 & 0.851 \\
\hline
\end{tabular}




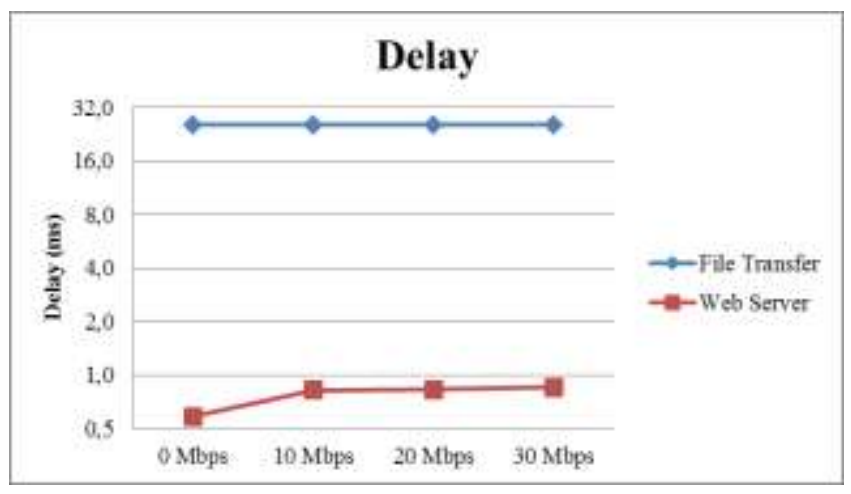

Gbr. 8 Grafik delay layanan file transfer dan web server

Dari tampilan grafik pada gambar 8 hasil rata-rata delay pada skenario dengan beban trafik $0 \mathrm{Mbps}$ pada layanan web server adalah sebesar $0.581 \mathrm{~ms}$, pada file transfer adalah sebesar $25.4637 \mathrm{~ms}$. Pada skenario penambahan beban trafik sebesar $10 \mathrm{Mbps}$, hasil rata-rata delay pada layanan web server adalah sebesar $0.824 \mathrm{~ms}$, pada file transfer adalah sebesar $25.5276 \mathrm{~ms}$. Pada skenario penambahan beban trafik sebesar $20 \mathrm{Mbps}$, hasil rata-rata delay pada layanan web server adalah sebesar $0.8272 \mathrm{~ms}$, pada file transfer adalah sebesar $25.5043 \mathrm{~ms}$. Hasil rata-rata delay pada skenario penambahan beban trafik sebesar $30 \mathrm{Mbps}$ layanan web server adalah sebesar $0.851 \mathrm{~ms}$, pada file transfer adalah sebesar $25.535 \mathrm{~ms}$.

Pada Gambar 8 nilai delay yang didapatkan adalah dalam satuan millisecond (ms). Nilai delay yang didapatkan dari hasil pengujian komunikasi menggunakan layanan file transfer dan web server pada jaringan IMS menggunakan NFV memiliki kategori yang baik sesuai dengan standarisasi delay dari TIPHON ETSI TR 101329 yang ditunjukkan pada Tabel 1, bahwa rentang nilai delay sebesar 0-100 ms maka nilai delay tersebut dikategorikan baik.

Dilihat dari Gbr 8 hasil nilai rata-rata delay pada layanan file transfer lebih besar dari pada nilai rata-rata delay pada layanan web server. Kondisi tersebut terjadi dikarenakan saat sesi komunikasi layanan web server data dikirim secara peer to peer. Hal tersebut dapat diamati pada SIP flows di software wireshark, di mana sesi komunikasi masih berlangsung dalam kondisi "IN CALL" namun file sudah sampai di user penerima.

\section{Hasil Analisis Jitter}

Jitter merupakan variasi kedatangan paket yang diakibatkan oleh variasi - variasi dalam panjang antrian, waktu lamanya pengolahan data, serta lamanya waktu penghimpunan atau pengurutan ulang paket - paket di sisi penerima. Besar kecilnya nilai jitter sangat dipenaruhi oleh delay/latency [4]. Hasil rata-rata parameter jitter pada jaringan IMS menggunakan NFV dalam skenario yang berbeda, yaitu dengan beban trafik 0 Mbps, 10 Mbps, 20 Mbps dan 30 Mbps ditunjukkan pada Tabel VI.
TABEL VI

\begin{tabular}{|c|c|c|c|c|c|}
\hline \multirow{3}{*}{ Layanan } & \multirow{3}{*}{ Parameter } & \multirow{2}{*}{\multicolumn{4}{|c|}{ Background Traffic }} \\
\hline & & & & & \\
\hline & & 0 Mbps & $10 \mathrm{Mbps}$ & 20 Mbps & 30 Mbps \\
\hline $\begin{array}{c}\text { File } \\
\text { Transfer }\end{array}$ & \multirow{2}{*}{ Jitter (ms) } & $\begin{array}{c}1.30116 \\
\times 10^{-7} \\
\end{array}$ & $\begin{array}{c}1.3011967 \\
\times 10^{-7} \\
\end{array}$ & $\begin{array}{c}1.301191 \\
\times 10^{-7} \\
\end{array}$ & $\begin{array}{c}1.30120797 \\
\times 10^{-7} \\
\end{array}$ \\
\hline $\begin{array}{l}\text { Web } \\
\text { Server }\end{array}$ & & 0.3455 & 0.4323 & 0.4532 & 0.4629 \\
\hline
\end{tabular}

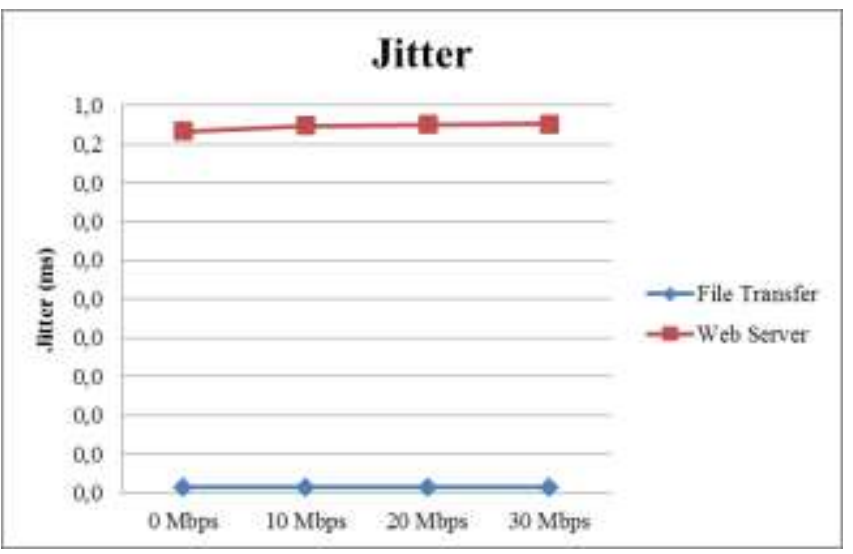

Gbr. 8 Grafik Jitter layanan file transfer dan web server

Hasil rata-rata jitter yang ditunjukkan pada Gambar 8 pada skenario dengan beban trafik 0 Mbps pada layanan file transfer adalah $1.30116 \times 10-7 \mathrm{~ms}$, pada layanan web server adalah sebesar $0.3455 \mathrm{~ms}$. Pada skenario penambahan beban trafik sebesar $10 \mathrm{Mbps}$, hasil rata-rata jitter pada layanan file transfer adalah sebesar $1.301197 \times 10-7 \mathrm{~ms}$, pada layanan web server adalah sebesar $0.4323 \mathrm{~ms}$.

Pada skenario penambahan beban trafik sebesar $20 \mathrm{Mbps}$, hasil rata-rata jitter pada layanan file transfer adalah sebesar 1.301191x10-7 ms, pada layanan web server adalah sebesar 0.4532 ms. Hasil rata-rata jitter pada skenario penambahan beban trafik sebesar $30 \mathrm{Mbps}$ dengan layanan file transfer adalah sebesar $1.30121 \times 10-7 \mathrm{~ms}$, pada layanan web server adalah sebesar $0.4629 \mathrm{~ms}$. Hasil nilai rata-rata jitter pada layanan web server lebih besar dari pada nilai rata-rata jitter pada layanan file transfer. Hal tersebut terjadi dikarenakan selisih dari variasi delay saat komunikasi berlangsung pada layanan web server memiliki selisih lebih besar dibandingkan dengan layanan file transfer.

Pada Gambar 8 nilai jitter yang didapatkan adalah dalam satuan millisecond (ms). Nilai jitter yang didapatkan dari hasil pengujian komunikasi menggunakan layanan file transfer dan web server pada jaringan IMS menggunakan NFV memiliki kategori yang baik sesuai dengan standarisasi jitter dari TIPHON TR 101329 yang ditunjukkan pada Tabel 2 , bahwa rentang nilai jitter sebesar 1-75 ms maka nilai jitter tersebut dikategorikan baik.

\section{Packet Loss}

Packet loss adalah presentase hilangnya paket yang dikirim pada saat paket IP sampai di IP tujuan, adanya packet loss disebabkan oleh beberapa faktor yang mencangkup penurunan signal dalam media transmit, paket yang corrupt yang menolak untuk transit, collision dan congestion, maupun kesalahan hardware jaringan [3]. 
Hasil rata-rata parameter packet loss pada layanan file transfer dan web server dalam skenario yang berbeda, yaitu dengan beban trafik 0 Mbps, 10 Mbps, 20 Mbps dan 30 Mbps ditunjukkan pada tabel 7 .

TABEL VII

PACKET LOSS LAYANAN FILE TRANSFER DAN WEB SERVER

\begin{tabular}{|c|c|c|c|c|c|}
\hline \multirow{2}{*}{ Layanan } & \multirow{2}{*}{ Parameter } & \multicolumn{4}{|c|}{ Background Traffic } \\
\cline { 3 - 6 } & & 0 Mbps & 10 Mbps & 20 Mbps & 30 Mbps \\
\hline File Transfer & Packet & 0 & 0 & 0 & 0 \\
\cline { 1 - 4 } & Loss (\%) & 0 & 0.0043 & 0.0145 & 0.0151 \\
\cline { 3 - 6 } & &
\end{tabular}

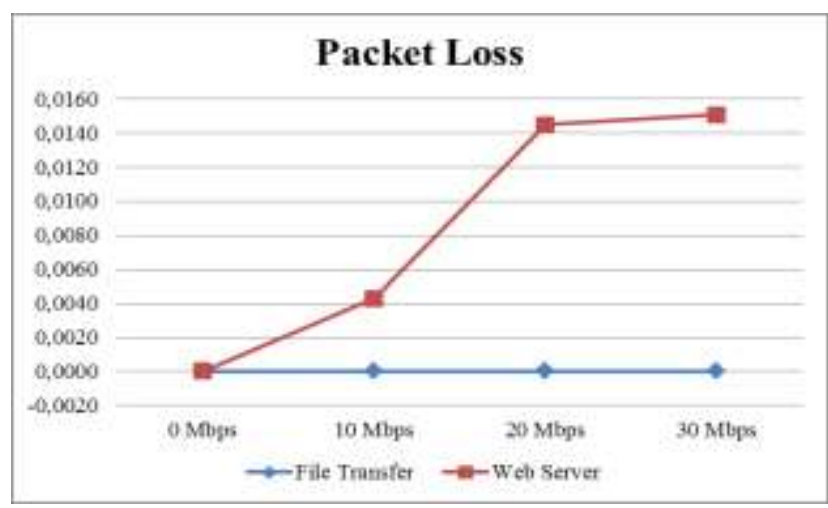

Gbr. 9 Grafik packet loss layanan file transfer dan web server

Berdasarkan gambar 9, Dari empat skenario yang berbeda pada penelitian ini, yaitu dengan beban trafik 0 Mbps, 10 Mbps, 20 Mbps dan 30 Mbps pada layanan file transfer prosentase packet loss yang dihasilkan adalah sebesar $0 \%$.

Sedangkan pada layanan web server pada skenario dengan beban trafik $10 \mathrm{Mbps}$ prosentase packet loss yang dihasilkan adalah sebesar $0.0043 \%$. Prosentase packet loss yang dihasilkan dari skenario penambahan beban trafik $20 \mathrm{Mbps}$ adalah sebesar $0.0145 \%$. Pada skenario penambahan trafik sebesar 30 Mbps menghasilkan prosentase packet loss sebesar $0.0151 \%$.

Prosentase packet loss yang didapatkan dari hasil pengujian komunikasi menggunakan layanan web server memiliki kategori yang baik sesuai dengan standarisasi packet loss dari TIPHON TR 101329 yang ditunjukkan pada Tabel 2.3, bahwa rentang nilai packet loss sebesar 1-3\% maka nilai packet loss tersebut dikategorikan baik. Munculnya parameter packet loss tersebut dikarenakan penambahan beban trafik dan saat sesi komunikasi dengan layanan web server. Meskipun web server menggunakan layer transport TCP, di mana seharusnya tidak terdapat packet loss karena bersifat connection-oriented. Namun terdapat packet loss saat pengujian hal ini sebenarnya adalah proses retransmisi paket data yang dikirim ulang oleh pengirim dikarenakan ada kegagalan paket sebelumnya.

\section{KESIMPULAN}

Implementasi Open IMS Core pada NFV Infrastucture berhasil dilakukan menggunakan OpenStack Devstack berdasarkan standarisasi QoS TIPHON TR 101329. Berdasarkan parameter throughput yang diperoleh dari skenario beban trafik, rata-rata nilai throughput pada layanan web server adalah $16.4366 \mathrm{Mbps}$ dan layanan file transfer adalah 0.2906 Mbps. Selisih nilai kedua layanan sebesar 16.146 Mbps. Parameter delay yang diperoleh pada layanan file transfer mendapatkan nilai rata-rata yang lebih besar yaitu 25.5077 ms dibandingkan pada layanan web server dengan rata-rata $0.7708 \mathrm{~ms}$. Selisih nilai delay sebesar $24.7369 \mathrm{~ms}$. Nilai delay yang dihasilkan masih dalam rentang baik. Parameter jitter yang diperoleh pada layanan file transfer memperoleh nilai jitter yang lebih kecil dibandingkan dengan layanan web server. Pada layanan file transfer memperoleh prosentase packet loss $0 \%$ di setiap beban trafik, sedangkan layanan web server memperoleh prosentase packet loss $0 \%$ hanya pada beban trafik 0 Mbps, dan pada beban trafik 10 Mbps, $20 \mathrm{Mbps}$, dan $30 \mathrm{Mbps}$ berturut-turut yaitu $0.0043 \%$, $0.0145 \%$, dan $0.0151 \%$. Prosentase packet loss yang diperoleh pada layanan web server dapat dianalogikan sebagai retransmisi paket.

\section{UCAPAN TERIMA KASIH}

Terimakasih kepada kedua orang tua dan keluarga atas do'a yang selalu dipanjatkan. Tak lupa pula bapak Dadiek Pranindito dan bapak Syariful Ikhwan selaku pembimbing dan semua pihak yang telah membantu dalam proses penelitian.

\section{DAFTAR PUSTAKA}

[1] A. Cánovas, M. Taha, J. Lloret, and J. Tomás, "Smart resource allocation for improving QoE in IP Multimedia Subsystems," J. Netw. Comput. Appl., vol. 104, pp. 107-116, Feb. 2018.

[2] B. Yi, X. Wang, K. Li, S. k. Das, and M. Huang, "A comprehensive survey of Network Function Virtualization," Comput. Networks, vol. 133, pp. 212-262, Mar. 2018.

[3] M. D. Ananth and R. Sharma, "Cost and Performance Analysis of Network Function Virtualization Based Cloud Systems," in 2017 IEEE 7th International Advance Computing Conference (IACC), 2017, pp. 70-74.

[4] F. R. Radhian, Y. Christyono, and S. Sukiswo, "IMPLEMENTASI LAYANAN INSTANT MESSAGING BERBASIS IP MULTIMEDIA SUBSYSTEM MENGGUNAKAN VIRTUAL SERVER," Transmisi, vol. 16, no. 1, pp. 7-12, Jan. 2014.

[5] S. S. Rajasekar and C. Palanisamy, "Optimized location-based service selection for QoS improvement in wireless networks," Comput. Electr. Eng., vol. 64, pp. 277-287, 2017.

[6] B. K. J. Al-Shammari, N. Al-Aboody, and H. S. Al-Raweshidy, "IoT Traffic Management and Integration in the QoS Supported Network," IEEE Internet Things J., vol. 5, no. 1, pp. 352-370, Feb. 2018.

[7] X. Q. Shao, "Based on two swarm optimized algorithm of neural network to prediction the switch's traffic of coal," Proc. - 2011 Int. Symp. Comput. Sci. Soc. ISCCS 2011, pp. 299-302, Jul. 2011.

[8] A. Roy, T. Acharya, and S. DasBit, "Quality of service in delay tolerant networks: A survey," Comput. Networks, vol. 130, pp. 121133, Jan. 2018.

[9] A. P. Silva, S. Burleigh, C. M. Hirata, and K. Obraczka, "A survey on congestion control for delay and disruption tolerant networks," Ad Hoc Networks, vol. 25, pp. 480-494, Feb. 2015. 